\title{
HUBUNGAN PENGETAHUAN GIZI ORANGTUA DAN PENDAPATAN ORANGTUA DENGAN KEPATUHAN ORANGTUA DALAM PENERAPAN DIET AUTIS PADA ANAK AUTIS DI SLB AUTIS LABORATORIUM UNIVERSITAS NEGERI MALANG
}

\author{
Poncowuri Handayani \\ Mazarina Devi \\ Agung Kurniawan \\ Fakultas Ilmu Keolahragaan Universitas Negeri Malang \\ email: poncowurih@gmail.com
}

\begin{abstract}
Autism is a behavioral deviation syndrome in children that involves sensory systems, communication skills, and socialization skills in community. Parental obedience in applying the diet should be consistent in order to reduce symptoms are undergone by children with autism. This study aims to determine the relationship between parental nutrition knowledge and parental income to parent's obedience of complience in the application of autism diet in children with autism in the SLB Autis Laboratorium Malang State University. The type of this research is quantitative research with cross sectional study design. Parental knowledge was measured from a knowledge questionnaire, and income was measured by the percapita income category per month and parental compliance was measured from Food Frequency Questionare (FFQ). The results showed that there was a significant correlation between parent's nutritional knowledge and parent's obedience to the application of the autism diet at SLB Autis Laboratorium Malang State University ( $p$ $=0,004$ ) and there was a significant correlation between parent's income with parent's obedience to the application of the autism diet at SLB Autis Laboratorium Malang State University $(p=0,020)$. Suggestions for the next research to conduct more detailed research about per capita income of family by considering another factor.
\end{abstract}

Keywords: knowledge, income, obedience, autism diet

\begin{abstract}
Abstrak: Autisme adalah suatu sindroma penyimpangan perilaku pada anak yang melibatkan sistem sensoris, kemampuan komunikasi, serta kemampuan sosialisasi dimasyarakat. Kepatuhan orang tua dalam menerapkan diet harus konsisten agar dapat mengurangi gejala yang dialami oleh anak autis. Penelitian ini bertujuan untuk mengetahui hubungan pengetahuan gizi dan pendapatan orangtua terhadap kepatuhan orangtua dalam penerapan diet autis pada anak autis di SLB Autis Laboratorium Universitas Negeri Malang. Jenis penelitian ini adalah penelitian kuantitatif dengan rancangan penelitian cross sectional. Pengetahuan orangtua diukur dari kuesioner pengetahuan, dan pendapatan diukur berdasarkan kategori pendapatan perkapita keluarga perbulan dan kepatuhan orangtua diukur dari Food Frequency Questionare (FFQ). Hasil penelitian menunjukkan bahwa terdapat hubungan yang signifikan antara pengetahuan gizi orangtua dengan kepatuhan orangtua dalam penerapan diet autis di SLB Autis Laboratorium Universitas Negeri Malang $(p=0,004)$ serta terdapat hubungan yang signifikan antara pendapatan orangtua dengan kepatuhan orangtua dalam penerapan diet autis di SLB Autis Laboratorium Universitas Negeri Malang $(\mathrm{p}=0,020)$. Saran bagi peneliti selanjutnya agar melakukan penelitian lebih mendetail lagi mengenai pendapatan perkapita keluarga dan dengan melihat faktor lain.
\end{abstract}

Kata kunci: pengetahuan, pendapatan, kepatuhan, diet aut is 
Autisme dikenal sebagai suatu sindroma penyimpangan perilaku pada anak yang melibatkan sistem sensoris, kemampuan komunikasi, serta kemampuan sosialisasi di masyarakat. Autis adalah gangguan perkembangan komunikasi (termasuk bahasa, perilaku yang terbatas dan berulang-ulang) (Mutianingrum, 2013).

Prevalensi autis di dunia saat ini mencapai 15-20 kasus per 10.000 anak atau $0,15-0,20 \%$, jika angka kelahiran di Indonesia enam juta per tahun, maka jumlah penyandang autis di Indonesia, bertambah $0,15 \%$ atau 6.900 anak per tahun, prevalensi anak laki-laki tiga sampai empat kali lebih besar dari pada anak perempuan (Mashabi \& Tajudin, 2009).

Berdasarkan data dari Badan Pusat Statistik (BPS) sejak 2010 dengan perkiraan hingga 2016, terdapat sekitar 140.000 anak dibawah usia 17 tahun menderita autis. Di Indonesia, menurut Goodwill Ambassador PBB Christine Hakim, prevalensi penyandang autisme saat ini sebanyak 8 dari 1.000 penduduk, prevalensi ini naik pesat dibandingkan data WHO 10 tahun yang lalu hanya 1 dari 1.000 penduduk (Kompas, 2011). Daerah Jawa Timur sampai saat ini belum ada data resmi berapa sebenarnya jumlah anak penderita autisme dikarenakan kehadiran anak autisme tidak menetap tiap semester (Murdiyanta, 2015).

Terdapat beberapa dugaan yang menyebabkan terjadinya kerusakan pada otak yang menimbulkan gangguan autisme diantaranya adanya pertumbuhan jamur Candida yang berlebihan di dalam usus. Akibat terlalu banyak jamur, maka sekresi enzim di dalam usus berkurang (Mc Candless, 2003). Kekurangan enzim pada anak autis menyebabkan makanan tak dapat dicerna dengan sempurna. Beberapa protein jika tidak dicerna secara sempurna akan menjadi membahayakan bagi tubuh anak autis.

Anak dengan kebutuhan khusus seperti autis cenderung memiliki alergi terhadap makanan. Perhatian orangtua terhadap pola makan sangat diperlukan. Pasalnya, asupan makanan akan mempengaruhi tingkah laku anak, autis dapat sembuh bila dilakukan intervensi secara dini, salah satunya adalah dengan memperhatikan pemberian makan pada anak autis (Eka, 2014).

Diet dapat membantu anak autisme karena perubahan diet, penambahan vitamin dan mineral khusus, dan pertimbangan untuk memberikan beberapa gizi lainnya dapat meningkatkan kondisi anak autisme (Zahra \& Warsiki, 2014). Terdapat beberapa terapi diet autis yang telah diajukan untuk memperbaiki atau menyembuhkan gangguan ini. Strategi diet autis yang telah diusulkan sebagai penanganan diantaranya yaitu: diet bebas jamur, diet GFCF (Gluten Free Casein Free), diet bebas bahan aditif, dan diet suplemen (Mujiyanti, 2011).

Hal yang sangat penting adalah orangtua harus bisa memperkaya pengetahuannya seputar tentang autisme, terutama dalam hal terapi yang tepat dan sesuai dengan anak (Marlina, 2015). Orangtua merupakan salah satu faktor yang sangat berpengaruh terhadap penerapan diet GFCF pada anak autisme karena pola makan pada anak dengan gangguan autisme tidak terlepas dari peran seorang ibu dalam menyediakan makanan yang baik serta bergizi dan sesuai dengan kebutuhannya (Rahmah dkk, 2015).

Faktor yang menyebabkan ketidakpatuhan orangtua dalam pemberian diet salah satunya adalah faktor pendidikan, semakin tinggi tingkat pendidikan formal orangtua maka semakin tinggi kemampuan mereka untuk menyerap informasi dengan demikian pengetahuan dan wawasannya tentang autis akan lebih luas sehingga dalam penanganannya juga lebih baik, pendidikan pasien dapat meningkatakan kepatuhan sepanjang bahwa pendidikan tersebut merupakan pendidikan yang diperoleh secara mandiri (Carpenito, 2000).

Berdasarkan penelitian Mashabi dan Tajudin (2009) disimpulkan bahwa tinggi rendahnya tingkat pengetahuan gizi seorang ibu akan mempengaruhi pola makan anak autis, yang artinya semakin tinggi pengetahuan gizi ibu dapat mempengaruhi pola makan anak autis dan sebaliknya. Menurut Purwanto dalam Marlina (2015) terdapat beberapa faktor yang mempengaruhi kepatuhan orangtua dalam menerapkan terapi diet bebas 
gluten dan bebas casein pada anak autis, diantarnya: faktor demografi, pengetahuan, komunikasi terapeutik, sikap, dan dukungan keluarga.

Besar kecilnya asupan nutrisi atau gizi tergantung pada apa yang terkandung dalam makanan yang dikonsumsi dan pemenuhan gizi keluarga tersebut tidak telepas dari pendapatan orangtua sebagai sumber dana yang utama (Amirudin, 2014). Menurut penelitian Amirudin (2014) faktor-faktor yang mempengaruhi status gizi antara lain konsumsi makanan, infeksi tingkat pendapatan, pengetahuan gizi serta sanitasi lingkungan yang baik. Konsumsi pangan yang cukup, baik kualitas maupun kuantitas yang tepat kepada setiap anggota keluarga sangat penting untuk mencapai gizi yang baik.

\section{METODE} pendekatan

Metode penelitian yang digunakan adalah kuantitatif dengan menggunakan sectional. Variabel bebas dalam penelitian ini adalah pengetahuan gizi orangtua dan pendapatan orangtua, sedangkan variabel terikat yaitu kepatuhan orangtua dalam penerapan diet. Subjek penelitian ini adalah semua orangtua siswa autis yang bersekolah di SD SLB Autis Laboratorium Universitas Negeri Malang.

Instrumen yang digunakan dalam penelitian ini yaitu dengan menggunakan kuesioner atau pedoman wawancara. Instrumen yang digunakan dalam penelitian ini berupa kuesioner yang berisi pertanyaan-pertanyaan untuk mengumpulkan data mengenai pengetahuan orangtua dan kaitannya dengan anak autis serta untuk mengetahui konsumsi dan pola konsumsi anak autis menggunakan instrumen Food Frequency Questionare (FFQ).

Variabel pengetahuan dengan pengisian kuesioner untuk melihat pengetahuan gizi orangtua menggunakan instrumen kuesioner skala Guttman yaitu skala yang menggunakan jawaban tegas "Benar" dan "Salah" diberi skor 1 dan pilihan jawaban "Salah/Tidak" diberi skor 0. Hasil pengisian kuesioner pengetahuan kemudian dikategorikan tinggi (baik) bila jawaban sesuai harapan sebesar 76-100\%, sedang (cukup) bila jawaban sesuai harapan sebesar 57-75\% dan rendah (kurang) bila jawaban sesuai harapan sebesar $<56 \%$ (Nursalam, 2008).

Variabel pendapatan orangtua didapatkan dari pengisian kuesioner pendapatan perkapita keluarga yaitu dimana pendapatan keluarga dibagi dengan jumlah anggota keluarga. Hasil pengisian data pendapatan dikategorikan menjadi data skala ordinal dengan kategori menurut World Bank yaitu tinggi 20\%, sedang 40\%, rendah $40 \%$ (Ariningsih, 2008).

Variabel Kepatuhan orangtua diukur dengan form food frequency questionare (FFQ). Pengisian form food frequency questionare yaitu dengan memberi tanda $\sqrt{ }$ (check list) pada kolom pilihan. Pengukuran kepatuhan menggunakan skala pengukuran Likert, yaitu dari 1 sampai 4. Hasil pengisian kuesioner kepatuhan kemudian dikategorikan patuh jika total jawaban responden memiliki nilai $>62,5 \%$ dan tidak patuh jika total jawaban responden memiliki nilai $<62 \%$ (Sugiono, 2015).

Analisis data dalam penelitian ini adalah dengan menggunakan uji statistik yang bertujuan untuk mengetahui hubungan pengetahuan gizi orangtua dan pendapatan orangtua dengan kepatuhan orangtua dalam menerapkan diet autis ini adalah chi square dengan derajat kemaknaan atau tingkat signifikasi $(\alpha)=0.05$. 


\section{HASIL PENELITIAN}

Hasil penelitian disajikan pada tabel berikut :

Tabel 1 Distribusi Pengetahuan Orangtua Anak Autis di SILB Autis Laboratorium Universitas Negeri Malang

\begin{tabular}{llcc}
\hline \multicolumn{1}{c}{ Skor } & Kategori & Jumlah Responden & Persentase (\%) \\
\hline $76 \%-100 \%$ & Tinggi & 14 & 54 \\
$57 \%-75 \%$ & Sedang & 4 & 15 \\
$<56 \%$ & Rendah & 8 & 31 \\
Total & & $\mathbf{2 6}$ & $\mathbf{1 0 0}$ \\
\hline
\end{tabular}

Tabel 1 menunjukkan bahwa dari 26 orangtua anak autis sebesar 14 orangtua memiliki pengetahuan gizi kategori tinggi dengan persentase 54\%. Kategori pengetahuan gizi sedang sebanyak 4 orangtua dengan persentase $15 \%$ dan dengan kategori pengetahuan gizi rendah sebanyak 8 orangtua dengan persentase $31 \%$.

Tabel 2 Distribusi Pendapatan Orangtua Anak Autis di SLB Autis Laboratorium Universitas Negeri Malang

\begin{tabular}{lcc}
\hline $\begin{array}{c}\text { Penghasilan Orangtua } \\
\text { Perkapita Perbulan }\end{array}$ & Frekuensi & Persentase (\%) \\
\hline $600.000-1.040 .000$ & 11 & 42 \\
$1.040 .001-1.480 .001$ & 12 & 46 \\
$1.480 .002-1.700 .002$ & 3 & 12 \\
\hline Total & $\mathbf{2 6}$ & $\mathbf{1 0 0}$ \\
\hline
\end{tabular}

Berdasarkan Tabel 2 dari hasil analisis distribusi penghasilan orangtua dibagi jumlah anggota keluarga didapatkan hasil sebesar $42 \%$ orangtua dengan pendapatan perkapita perbulan dalam kategori rendah yaitu berjumlah 11 orang, $46 \%$ dengan kategori sedang yaitu berjumlah 12 orang dan $12 \%$ atau dengan jumlah 3 orang kategori tinggi.

Tabel 3 Distribusi Kepatuhan Orangtua Anak Autis dalam Penerapan Diet Autis di SLB Autis Laboratorium Universitas Negeri Malang

\begin{tabular}{lcc}
\hline \multicolumn{1}{c}{ Kepatuhan Orangtua } & Frekuensi & Persentase (\%) \\
\hline Patuh & 15 & 58 \\
Tidak Patuh & 11 & 42 \\
\hline Total & $\mathbf{2 6}$ & $\mathbf{1 0 0}$ \\
\hline
\end{tabular}


Handayani, dkk, Hubungan Pengetahuan Gizi Orangtua dan Pendapatan Orangtua dengan |5 Kepatuhan Orangtua dalam Penerapan Diet Autis Pada Anak Autis di Slb Autis

Laboratorium Universitas Negeri Malang

Berdasarkan Tabel 3 dapat diketahui bahwa dari 26 orangtua anak autis sebesar 15 orangtua memiliki kepatuhan yang baik dengan persentase $58 \%$ dan 11 orangtua yang memiliki kepatuhan tidak baik dengan persentase $42 \%$.

Tabel 4 Hubungan Antara Pengetahuan Gizi Orangtua dengan Kepatuhan orangtua dalam Penerapan Diet Autis Pada Anak Autis di SLB Autis Laboratorium Universitas Negeri Malang

\begin{tabular}{|c|c|c|c|c|c|c|}
\hline \multirow{3}{*}{ Pengetahuan } & \multicolumn{4}{|c|}{ Kepatuhan } & \multirow{2}{*}{\multicolumn{2}{|c|}{ Total }} \\
\hline & \multicolumn{2}{|c|}{ Patuh } & \multicolumn{2}{|c|}{ Tidak Patuh } & & \\
\hline & $\mathrm{N}$ & $\%$ & $\mathrm{~N}$ & $\%$ & $\mathrm{~N}$ & $\%$ \\
\hline Tinggi & 12 & $86 \%$ & 2 & $14 \%$ & 14 & $100 \%$ \\
\hline Sedang & 2 & $50 \%$ & 2 & $50 \%$ & 4 & $100 \%$ \\
\hline Rendah & 1 & $12,5 \%$ & 7 & $87,5 \%$ & 8 & $100 \%$ \\
\hline Total & 15 & $58 \%$ & 11 & $42 \%$ & 26 & ${ }^{100}$ \\
\hline
\end{tabular}

Tabel 4 menunjukkan bahwa tingkat pengetahuan orangtua memberi dampak positif terhadap kepatuhan orangtua dalam penerapan diet autis. Hal ini dapat dilihat dari total 14 responden yang memiliki pengetahuan gizi autis dengan kategori tinggi, 86\% atau 12 orang patuh dan $14 \%$ atau 2 orang tidak patuh. Pengetahuan gizi dengan kategori rendah dari total 8 responden, 1 orang patuh dan 7 orang tidak patuh. Hasil uji chi square nilai probabilitas Asymp Sig sebesar 0,004, karena nilai probabilitas < nilai a 0,05 maka $\mathrm{H}_{1}$ diterima dan Ho ditolak. Hal ini berarti terdapat hubungan yang signifikan antara pengetahuan gizi orangtua dengan kepatuhan orangtua dalam penerapan diet autis di SLB Autis Laboratorium Universitas Negeri Malang.

Tabel 5 Hubungan Antara Pendapatan Orangtua dengan Kepatuhan orangtua dalam Penerapan Diet Autis Pada Anak Autis di SLB Autis Laboratorium Universitas Negeri Malang

\begin{tabular}{|c|c|c|c|c|c|c|}
\hline \multirow{3}{*}{ Pendapatan } & \multicolumn{4}{|c|}{ Kepatuhan } & \multirow{2}{*}{\multicolumn{2}{|c|}{ Total }} \\
\hline & \multicolumn{2}{|c|}{ Patuh } & \multicolumn{2}{|c|}{ Tidak Patuh } & & \\
\hline & $\mathrm{N}$ & $\%$ & $\mathrm{~N}$ & $\%$ & $\mathrm{~N}$ & $\%$ \\
\hline Tinggi & 3 & $100 \%$ & 0 & $0 \%$ & 3 & 100 \\
\hline Sedang & 9 & $75 \%$ & 3 & $25 \%$ & 12 & 100 \\
\hline Rendah & 3 & $27 \%$ & 8 & $73 \%$ & 11 & 100 \\
\hline Total & 15 & $58 \%$ & 11 & $42 \%$ & 26 & 100 \\
\hline
\end{tabular}

Tabel 5 menunjukkan bahwa tingkat pendapatan orangtua memberi dampak positif terhadap kepatuhan orangtua dalam penerapan diet autis. Hal ini dapat dilihat dari total 11 responden yang memiliki pendapatan dengan kategori rendah, $73 \%$ atau 8 orang tidak patuh dan $27 \%$ atau 3 orang patuh. Hasil uji chi square nilai probabilitas Asymp Sig sebesar 0,020, karena nilai probabilitas $<$ nilai $\alpha 0,05$ maka $\mathrm{H}_{1}$ diterima dan Ho ditolak. Hal ini berarti terdapat hubungan yang signifikan antara pendapatan orangtua dengan kepatuhan orangtua dalam penerapan diet autis di SLB Autis Laboratorium Universitas Negeri Malang.

\section{PEMBAHASAN}

1. Hubungan Pengetahuan Gizi Orangtua dengan Kepatuhan Orangtua dalam Penerapan Diet Autis Pada Anak Autis di SLB Autis Laboratorium Universitas Negeri Malang

Berdasarkan analisis antara tingkat pengetahuan orangtua dengan kepatuhan orangtua dalam penerapan diet autis pada anak autis di SLB Autis Laboratorium Universitas Negeri Malang dengan menggunakan chi square didapatkan hasil p-value sebesar 0,004 karena $p$-value $<0,05$ maka Ho ditolak dan Ha diterima, artinya terdapat 
hubungan yang signifikan antara tingkat pengetahuan orangtua dengan kepatuhan orangtua dalam penerapan diet autis pada anak autis. Hal ini menunjukkan bahwa orangtua anak autis di SLB Autis Laboratorium Universitas Negeri Malang rata-rata memiliki pengetahuan yang baik terhadap pemahaman tentang diet yang harus dijalani oleh anak autis.

Hal ini sejalan dengan penelitian sebelumnya oleh Alisa (2014) yang menjelaskan bahwa semakin tinggi tingkat pendidikan orangtua serta semakin banyak pengalaman yang di dapatkan oleh orangtua, maka akan semakin baik pula pengetahuan orang tua sehingga orangtua menjadi patuh dalam menerapkan diet autis. Penelitian sejenisnya juga dilakukan oleh Mashabi dan Tajudin (2009) dalam penelitiannya dijelaskan bahwa dengan memiliki pengetahuan gizi khususnya gizi yang dibutuhkan anak autis maka ibu dapat menyusun pola makan yang baik bagi anak autis. Hal tersebut menjelaskan bahwa pengetahuan gizi orangtua berpengaruh dalam pola makan anak.

Menurut penelitian Murdiyanta dkk (2015) sikap seorang ibu termasuk kepatuhan terhadap pemberian makan pada anak sangat dipengaruhi oleh pengetahuan, keyakinan, dan emosi. Perilaku yang didasari pengetahuan akan lebih lama bertahan atau lebih konsisten daripada perilaku yang tidak didasari oleh pengetahuan. Pengetahuan gizi orangtua berdampak positif terhadap kepatuhan orangtua menurut Rahmah (2015) pada anak autis dianjurkan untuk berdiet selain dapat memperbaiki gangguan pencernaan, diet autis juga dapat mengurangi gejala atau tingkah laku autistik. Hal ini dapat dilakukan dengan memperhatikan asupan makanan anak autis. Penelitian Hardiansyah (2007) mengatakan bahwa orangtua memegang peranan penting dalam pemilihan pangan untuk keluarga, maka pengetahuan gizi akan mempengaruhi jenis pangan dan mutu gizi makanan yang akan dikonsumsi anggota keluarga.

\section{Hubungan Pendapatan Orangtua Dengan Kepatuhan Orangtua Dalam Penerapan Diet Autis Pada Anak Autis Di SLB Autis Laboratorium Universitas Negeri Malang}

Berdasarkan analisis antara pendapatan orangtua dengan kepatuhan orangtua dalam penerapan diet autis pada anak autis di SLB Autis Laboratorium Universitas Negeri Malang dengan menggunakan chi square didapatkan hasil p-value sebesar 0,020 karena $p$-value $<0,05$ maka Ho ditolak dan Ha diterima, artinya terdapat hubungan yang signifikan antara pendapatan orangtua dengan kepatuhan orangtua dalam penerapan diet autis pada anak autis.

Hasil penelitian di lapangan sejalan dengan penelitian dari Murdiyanta dkk (2015) bahwa tingkat pendapatan merupakan faktor yang menentukan kualitas dan kuantitas makanan yang dikonsumsi. Mujiyanti (2011) mengatakan bahwa diketahui alokasi biaya yang dikeluarkan untuk merawat anak autis harus memiliki pendapatan yang tinggi karena anak autis memiliki beberapa gangguan ditubuhnya. Pendapatan yang tinggi akan meningkatkan daya beli sehingga keluarga mampu membeli pangan dalam jumlah yang diperlukan dan sesuai dengan kebutuhan dalam tubuh sehingga memberi dampak positif terhadap gizi individu. Syafitri (2008) dalam penelitiannya juga berpendapat bahwa anak autis membutuhkan biaya yang lebih besar daripada anak normal, hal ini membuat pendapatan keluarga sangat menentukan seorang anak autis untuk mendapatkan berbagai hal yang dapat menunjang perkembangan anak autis termasuk dalam hal konsumsi makanan sehari-hari.

Penelitian Hardiansyah (2007) mengatakan bahwa kelompok orang dengan pendapatan yang lebih tinggi kemungkinan memiliki pengalaman dibidang gizi yang lebih baik jika dibandingkan dengan kelompok orang dengan pendapatan rendah. Penelitian Sartika (2015) menyimpulkan bahwa ekonomi merupakan salah satu faktor yang mendukung kepatuhan orang tua dalam menjalankan terapi diet glutein dan casein, pada anak penyandang autis, seperti yang telah disampaikan oleh orang tua di yayasan 
Rumah Autis Cahaya Fitrah Cemerlng Jatiasih Bekasi, bahwa mereka kesulitan ketika harus menyediakan makanan yang berbeda dari adik atau kakaknya karna mengeluarkan biaya yang lebih. Hal tersebut dapat dikatakan bahwa pendapatan ekonomi keluarga adalah penunjang dalam memenuhi kebutuhan keluarga.

Menurut penelitian Amirudin (2014) besar kecilnya asupan nutrisi atau gizi tergantung pada apa yang terkandung dalam makanan yang dikonsumsi dan pemenuhan gizi keluarga tersebut tidak terlepas dari pendapatan orangtua sebagai sumber dana utama. Penghasilan merupakan faktor penting bagi kuantitas dan kualitas dalam konsumsi keluarga.

\section{KESIMPULAN}

Berdasarkan hasil penelitian pada orangtua anak autis di SLB Autis Laboratorium Universitas Negeri Malang tentang kepatuhan penerapan diet untuk anak autis kesimpulan sebagai berikut:

1. Tingkat pengetahuan gizi orangtua anak autis di SLB Autis Laboratorium Universitas Negeri Malang termasuk dalam kategori baik (tinggi).

2. Tingkat pendapatan orangtua anak autis di SLB Autis Laboratorium Universitas Negeri Malang sebesar 46\% memiliki pendapatan sedang.

3. Orangtua anak autis di SLB Autis Laboratorium Universitas Negeri Malang berjumlah 15 orang atau $58 \%$ dari total responden patuh dalam penerapan diet autis.

4. Terdapat hubungan antara pengetahuan orangtua anak autis dengan kepatuhan orangtua anak autis dalam penerapan diet bagi anak autis di SLB Autis Laboratorium Universitas Negeri Malang.

5. Terdapat Hubungan antara pendapatan orangtua anak autis dengan kepatuhan orangtua anak autis dalam penerapan diet bagi anak autis di SLB Autis Laboratorium Universitas Negeri Malang.

\section{SARAN}

Dengan memperhatikan hasil penelitian, pembahasan, dan kesimpulan, maka saran yang dapat diberikan adalah:

1. Penelitian ini diharapkan dapat menjadi bahan masukan informasi dan referensi kepustakaan untuk menambah ilmu pengetahuan tentang faktor-faktor yang berhubungan dengan kepatuhan orangtua dalam menerapkan diet bebas gluten dan bebas casein pada anak autis.

2. Diharapkan kepada orangtua yang memiliki anak dengan gangguan autis untuk lebih konsisten melakukan penerapan diet pada menu makanan anak dan diharapkan kepada orangtua untuk mengingatkan orang-orang di rumah dan keluarga yang lain agar tidak memberikan makanan yang tidak dianjurkan bagi anak autis. Pemberian alternatif makanan pengganti dengan cara masak sendri dapat membantu dalam penerapan diet autis.

3. Diharapkan pada peneliti selanjutnya agar melakukan penelitian lebih mendetail lagi mengenai pendapatan perkapita keluarga dan dengan melihat faktor lain yang berhubungan dengan kepatuhan orangtua dalam menerapkan diet pada anak autis, seperti demografi, keyakinan dan sikap orangtua atau diharapkan kepada peneliti selanjutnya untuk dapat mengembangkan penelitian mengenai pengaruh diet pada anak autis terhadap perkembangan anak autisme.

\section{DAFTAR RUJUKAN}

Amirudin, M, M. 2014. Hubungan Antara Pendapatan Orang Tua Dengan Status Gizi Pada Siswa SDN di Tenggong Rejotangan Tulungagung. Jurnal Pendidikan Olahraga dan Kesehatan. 2(3): 564-568. Surabaya: Fakultas Ilmu Keolahragaan Universitas Negeri Surabaya. 
Ariningsih, E. 2008. Konsumsi dan Kecukupan Energi dan Protein Rumah Perdesaan di Indonesia. Artikel disajikan dalam, Seminar Nasional Dinamika Pembangunan Pertanian dan Perdesaan, Pusat Analisis Sosial Ekonomi dan Kebijakan Pertanian.

Alisa, N. 2014. Hubungan Kepatuhan Orang Tua Menerapkan Diet Bebas Gluten Dan Kasein (GFCF) Dengan Perilaku Anak Autis Di Yayasan Autis Center "Cakra" Pucang Jajar Surabaya. Surabaya: STIKES Hang Tuah Surabaya

Carpenito, L, Juall., \& Ester, M. 2000. Diagnosa Keperawatan, Aplikasi Pada Praktik Klinis. Jakarta: ECG.

Eka, E. E. 2014. Gambaran Pengetahuan Dan Sikap Ibu Tentang Gizi Seimbang Dan Pola Makan Anak Autis Di Sdlbn 107708 Lubuk Pakam Tahun 2012. Skripsi. Medan. Kesehatan Masyarakat USU.

Hardiansyah. 2007. Review Faktor Determinan Keragaman Konsumsi Pangan. Jurnal Gizi dan Pangan. 2(2): 55-74.

Marlina, H. 2015. Faktor-Faktor Yang Berhubungan Dengan Kepatuhan Orangtua Dalam Menerapkan Diet Bebas Gluten dan Bebas Casein Pada Anak Autis di Yayasan Autis Mitra Ananda Padang. Padang: Keperawatan Universitas Andalas.

Mashabi, A. N., \& Tajudin, R, N. 2009. Pengetahuan Gizi Ibu Dan Pola Makan Anak Autis. Journal Makara Kesehatan. 13(2): 88-90. Jakarta: Teknik Universitas Negeri Jakarta.

Mc Candless, J. 2003. Children with Starving Brains Anak-anak dengan Otak yang "Lapar": Panduan penanganan medis untuk penyandang gangguan spektrum autisme, ed.2. Terjemah: F. Siregar. Jakarta: Gramedia Widiasarana Indonesia.

Mujiyanti, D. M. 2011. Tingkat Pengetahuan Ibu Dan Pola Konsumsi Pada Anak Autis Di Kota Bogor. Bogor : Ekologi Manusia IPB.

Mulyadi, A. 4 Mei 2011. Penyandang Meningkat Delapan Kali Lipat. Kompas. (Online), (http://health.

kompas.com/read/2011/05/04/21480480/penyandang.meningkat.delapan.kali.lipa t), diakses tanggal 25 Oktober 2016.

Mutianingrum, A. 2013. Hubungan Tingkat Pengetahuan Ibu dengan Pemberian Diet Bebas Gluten, Kasein dan Status Gizi Pada Anak Autis. Skripsi. Yogyakarta: UGM.

Murdiyanta, C. C., Sulistiyani., \& Ramani, A. 2015. Faktor Ibu Dalam Pemilihan Makanan Pada Anak Autis di Sekolah Luar Biasa Arya Satya Hati Kota Pasuruan. Jember: Universitas Jember.

Nursalam. 2008. Konsep \& Penerapan Metodologi Penelitian Ilmu Keperawatan: Pedoman Skripsi, Tesis, dan Instrumen Penelitian Keperawatan. Jakarta: Salemba Medika.

Rahmah, J., Diani, N. \& Rachmawati, K. 2015. Kepatuhan Orangtua Tentang Diet Gluten Free dan Casein Free Dengan Perilaku Anak Autis. 3(2): 16-25.

Sartika, M. 2015. Faktor-Faktor Yang Berhubungan Dengan Kepatuhan Orang Tua Terhadap Terapi Diet Gfcf (Glutein Free-Casein Free) Pada Anak Usia 3-5 Tahun Penyandang Autis Di Rumah Autis Cahaya Fitrah Cemerlang Jatiasih Kota Bekasi Tahun 2015. Jurnal Ilmiah Keperawatan STIKes Medika Cikarang 2015. 5 (1): 64-73.

Sugiyono. 2015. Metode Penelitian Kuantitatif Kualitatif dan $R$ \& B. Bandung: Alfabeta.

Syafitri, I. 2008. Pengasuhan (Makan, Hidup Sehat, Dan Ermain), Konsumsi Dan Status Gizi Penderita Autism Spectrum Disorder (Asd). Bogor: Program Studi Gizi Masyarakat Dan Sumberdaya Keluarga Fakultas Pertanian Institut Pertanian Bogor

Zahra, Z., \& Warsiki, E. 2014. Biomedic Aspect On Autisme Focuesd to Diet And Nutrition. Jurnal Psikiatri Surabaya. 3(1): 1-10. 